\title{
Дискуссия о датировке квестуры Л. Лициния Лукулла и надпись из Мопсуестии: проблема обозначения должностного статуса
}

\author{
Дементьева В.В. \\ Ярославский государственный университет им. П.Г. Демидова \\ 15003, Россия, г. Ярославль, ул. Советская, 14 \\ vv.dementieva@mail.ru
}

\begin{abstract}
Аннотация. Статья посвящена историографическому анализу дискуссионной проблемы датировки занятия Л. Лицинием Лукуллом магистратуры квестора (и, соответственно, промагистратуры проквестора, последовавшей после нее). Дискуссия по этому вопросу, которая была начата в 70-е гг. XIX в., не может, на взгляд автора, считаться законченной, поскольку обнаружение в 80 -е гг. XX в. надписи на греческом языке из Мопсуестии ${ }^{21}$ требует внесения корректив в представления историков о полномочиях Лукулла в 80 -е гг. І в. до н. э. В той части инскрипции, которая понимается как официальное письмо Лукулла властям и жителям

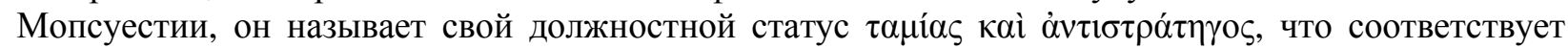
латинскому его обозначению как quaestor pro praetore. Временем составления письма Лукулла публикаторы надписи называют 86 г. до н. э., что входит в противоречие с имеющимися в научной литературе датировками квестуры Лукулла - 88 или 87 гг. до н. э., в связи с чем возникают вопросы об обозначении в эпиграфике должностного статуса квесторов и проквесторов, особенно при получении ими полномочий pro praetore. Автор статьи суммирует высказанные в историографии точки зрения, фиксируя значительный разброс мнений. Делается вывод о том, что для понимания конкретной ситуации Л. Лициния Лукулла и уточнения года занятия им магистратуры квестора, необходимо проанализировать имеющуюся информацию обо всех известных случаях функционирования квесторов/проквесторов pro praetore, - это даст возможность рассмотреть статус Лукулла в контексте римской практики предоставления низшим магистратам и промагистратам преторских полномочий.
\end{abstract}

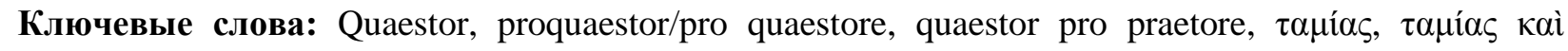

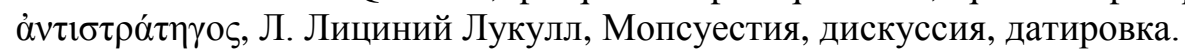

Для цитирования: Дементьева В.В. 2021. Дискуссия о датировке квестуры Л. Лициния Лукулла и надпись из Мопсуестии: проблема обозначения должностного статуса. Via in tempore. История. Политология, 48 (3): 536-545. DOI 10.52575/2687-0967-2021-48-3-536-545.

\section{The controversy over the date of q. Licinius Lucullus' quaestorship and the inscription from Mopsuestia: the terminology for describing public offices}

\author{
Vera V. Dementyeva \\ P.G. Demidov Yaroslavl State University, \\ 14 Sovetskaya St., Yaroslavl, 150003, Russia \\ vv.dementieva@mail.ru
}

\begin{abstract}
This paper charts the scholarly debates about the date of L. Licinius Lucullus' quaestorship (and, therefore, his proquaestorship). The issue has been under discussion since the 1870s and is still far
\end{abstract}

${ }^{21}$ Supplementum Epigraphicum Graecum XLIV. 1227. 
from being resolved given the discovery in the 1980s of a Greek inscription from Mopsuestia ${ }^{22}$ which compels us to reconsider Lucullus's official position in the $80 \mathrm{~s} \mathrm{~B}$. C. In the section which has been recognized by modern researchers as Lucullus' official letter to the authorities and the people of

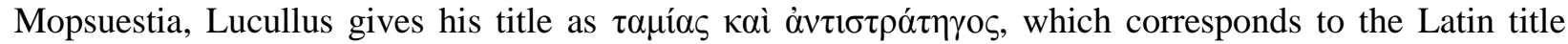
quaestor pro praetore. The first editors of the inscription date the letter of Lucullus to $86 \mathrm{~B}$. C, which contradicts the earlier scholarly suggestions to place Lucullus' quaestorship in 88 or $87 \mathrm{~B}$. C. In this connection, it is important to ask about the specificity of the epigraphical terminology for quaestors and proquaestors, especially in the cases where these officials were given power pro praetore. This paper reviews the wide variety of incompatible modern views on these issues and argues that the key to clarifying the specific situation of L. Licinius Lucullus and the date of his quaestorship is to study the evidence on all known cases of the activities of quaestors/proquaestors pro praetore. This will make it possible to examine Lucullus's position within the general context of the Roman practice of granting praetorian powers to the lower magistrates and promagistrates.

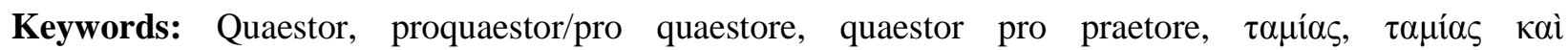
$\dot{\alpha} v \tau \imath \sigma \tau \rho \alpha ́ \tau \eta \eta \gamma ం \varsigma$, L. Licinius Lucullus, Mopsuestia, discussion, dating.

For citation: Dementyeva V.V. 2021. The controversy over the date of q. Licinius Lucullus' quaestorship and the inscription from Mopsuestia: the terminology for describing public offices. Via in tempore. History and political science, 48 (3): 536-545 (in Russian). DOI 10.52575/2687-0967-2021-483-536-545.

\section{Введение}

Дискуссионное обсуждение датировки квестуры Лукулла в историографии длится уже полтора века, но на данный момент не может, на наш взгляд, считаться завершенным, поскольку находка в 80-е гг. XX в. надписи из Мопсуестии ${ }^{23}$, поставила новые вопросы, теснейшим образом связанные с этой дискуссией. Это обусловливает необходимость внимательно проанализировать дискуссию, сопоставляя аргументацию исследователями их позиций и акцентируя попытки разрешить противоречия, возникшие после обнаружения названной надписи, а также выделить и суммировать точки зрения по поводу должностного статуса Лукулла и терминологии его обозначения.

\section{Результаты и их обсуждение}

Проследим развитие дискуссии, отмечая ее узловые моменты. Первым задумался над отнесением квестуры Лукулла к определенному году Теодор Моммзен (заметим, что о его приоритете в постановке данного вопроса обычно забывают; никто из тех, кто в XX и XXI вв. занимался этим сюжетом, о его приоритете не вспомнил). Т. Моммзен, видимо, сразу оценив ситуацию с сообщениями источников ${ }^{24}$, колебался в своей датировке квестуры Луция Лукулла между 88 и 87 г. до н. э., комментируя латинскую надпись с о. Делос с упоминанием проквестуры Лукулла [Corpus, 1873, p. 1303]. Этой позиции T. Моммзена придерживался и Эрнст Ломматч [Corpus, 1918, p. 530], заново воспроизводя текст надписи и публикуя ее фотографию.

Затем возобладало мнение, что квестуру Луция Лукулла следует отнести к 88 г. до н. э. Так поступали Уильям Митчелл Рамсей, когда он изучал надпись из Синнады ${ }^{25}$

22 Там же.

23 Там же.

${ }^{24}$ В нарративной традиции противоречие заложено, например, в словах псевдо-Аврелия Виктора о том, что Лукулл «...будучи квестором, устроил роскошные зрелища народу. Затем через Мурену он передал консулу Сулле флот Митридата...» (Aurel. Vict. Vir. Ill. 74. 1-2. Пер. В.В. Соколова). Следовательно, получается, что во время консулата Суллы он был квестором, а консулат Суллы относится в 88 г. до н. э., но события, в которых Лукулл разбил флот Митридата, исследователи относят к 87 г. до н. э.

${ }^{25}$ Inscriptiones Graecae ad Res Romanas Pertinentes 4. 701; Monumenta Asiae Minoris Antiqua IV. 52. 
[Ramsay, 1883, p. 298], и Мишель Арманд Клерк, анализировавший надпись из Фиатиры ${ }^{26}$ [Clerc, 1886, p. 399], а также Германн Дессау при воспроизведении надписи с о. Делос [Inscriptiones, 1892, p. 19, 194]. С этим же годом связывали квестуру Лукулла Фридрих Зобек в диссертации о квесторах республиканского времени [Sobeck, 1909, S. 29] и Феликс Дюррбах [Choix, 1923, p. 243-244], датировавший квестуру Лукулла 88 г. до н. э. на том основании, что одна надпись ${ }^{27}$ называет его квестором (относится к фессалийской территории Греции, из Гипаты), а другая надпись, с о. Родос ${ }^{28},-$ проквестором ${ }^{29}$.

Однако уже в начале 20-х гг. ХХ в. Ханс Помтов определял годом квестуры Л. Лициния Лукулла 87 г. до н. э. [Pomtow, 1921, S. 163-164]. Он анализировал греческую надпись из Дельф, в которой весьма вероятным, судя по сохранившейся части слова, является упоминание квесторской должности, но от имени ее носителя остались только пять букв генетивного окончания, позволяющие считать, что речь идет о сыне Луция, тогда как семейное имя отсутствует. Она была опубликована сначала X. Помтовом в журнале «Клио», а через два года в первом томе Supplementum Epigraphicum Graecum ${ }^{30}$. В историографии реконструкцию Х. Помтова практически не восприняли [см., например: Ameling, 1989, S. 99. Anm. 10; Sayar, Siewert, Taeuber, 1994, S. 118. Anm. 13], хотя она, по нашему мнению, заслуживает внимания [см.: Дементьева, 2015, с. 119-125].

К концу 20-х гг. XX в. с выходом XIII тома энциклопедии Георга Виссова, содержащего статью Маттиаса Гельцера о Л. Лицинии Лукулле, где он отнес квестуру Лукулла к 87 г. до н. э. [Gelzer, 1926, S. 377], мнение о том, что ее следует датировать именно так, стало более распространенным. Этой даты, 87 г. до н. э., придерживались автор биографического труда о Лукулле Жюль ван Оотехем [Ooteghem, van, 1959, p. 19] и поначалу Томас Роберт Броутон [Broughton, 1986b, p. 47], фундированный справочник которого вышел первым изданием ранее книги Ж. ван Оотехема, в начале 50-х гг.

К середине 60-х гг. в дискуссии начался новый этап. Эрнст Бэдиан вернулся к датировке квестуры Лукулла 88 г. до н. э. [Badian, 1964, p. 220]. Он аргументировал такую позицию тем, что, по сообщению Аппиана ${ }^{31}$, Суллу в его первом походе на Рим из военных командиров поддержал только один квестор, не названный по имени римским историком, которым, на взгляд Э. Бэдиана, мог быть именно Л. Лициний Лукулл, всегда остававшийся ему верным. Датировка Э. Бэдиана была поддержана Артуром Кивни [Keaveney, 1992, р. 17-18] и заставила Т.Р. Броутона изменить в третьем томе его справочного издания свое первоначальное мнение [Broughton, 1986a, p. 121]. Такая датировка получила, очевидно, в силу авторитета Э. Бэдиана и Т.Р. Броутона широкое распространение в работах о Сулле и сопредельным темам, изданных до середины 90-х гг. XX в. [см.: Schütz, 1994, S. 54. Anm. 10].

Но возврат к более ранней датировке вызвал категорическое несогласие Гюнтера Шютца [Schütz, 1994, S. 54-58], посвятившего свою диссертацию раннему периоду карьеры Л. Лициния Лукулла. Г. Шютц обосновывал датировку 87 годом тем, что надпись из Балканской Греции, из Гипаты ${ }^{32}$, содержит название должности Л. Лукулла как $\tau \alpha \mu i ́ \alpha$ (квестор), в противоположность пяти (он так считал) надписям из малоазийских и островных центров (Эфеса, Синнады, Фиатиры, Родоса и Делоса), в которых Лукулл назван уже

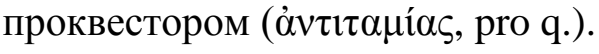

\footnotetext{
${ }^{26}$ Corpus Inscriptionum Latinarum I. P. 1305; IGR. IV. 1191; Tituli Asiae Minoris V. 2. 918.

${ }^{27}$ Sylloge Inscriptionum Graecarum ${ }^{3}$ № 743.

${ }^{28}$ Sylloge Inscriptionum Graecarum ${ }^{3}$ № 745.

${ }^{29}$ О надписях из Гипаты, Синнады, Фиатиры и с Родоса см.: [Дементьева, 2013а, с. 14-19] О надписи с о. Родос см. также: [Дементьева, 2019, с. 53-67].

${ }^{30}$ Supplementum Epigraphicum Graecum I. 153.

${ }^{31}$ Арp. В.С. I. 57: «Командиры войска, за исключением лишь одного квестора, не соглашаясь вести войско против своей родины, убежали в Рим» (пер. под ред. С.А. Жебелева и О.О. Крюгера).

${ }^{32}$ Inscriptiones Graecae IX.2. 38= Sylloge Inscriptionum Graecarum ${ }^{3}$ № 743.
} 
Г. Шютц подробно объяснил, что Л. Лукулл не мог ранее 87 г. до н. э. вступить на греческую землю в качестве магистрата, и только один год из многих лет, проведенных им на Востоке, собственно 87 г. до н. э., и находился в Греции. Г. Шютц отверг точку зрения Бернхарда Возника, высказанную в его диссертации [Wosnik, 1963, S. 51] ${ }^{33}$, о том, что для датировки не имеет значения место находки. Отрицание Б. Возником отнесения квестуры Л. Лукулла к 87 г. до н. э. строилось на том, что, во-первых, надпись из Гипаты исходила не от римлян, а от греков, а, во-вторых, пророгация в I веке до н. э. не была необходимой [Wosnik, 1963, S. 50-51]. Оппонируя этому выводу, Г. Шютц подчеркивал, что вообще все известные надписи о почитании Лукулла исходили не от римлян (в лучшем случае почести ему воздавали италики), и не понятно, почему именно община энианов должна была в надписи из Гипаты использовать неверную терминологию [Schütz, 1994, S. 58]; к тому же речь идет не о всем I веке до н. э., а только о двух его десятилетиях, а именно о том времени, о котором сам Б. Возник писал, что пророгированная магистратура обычно отмечалась в ее названии.

Казалось, что вопрос о датировке квестуры (и, соответственно, начала проквестуры) Л. Лициния Лукулла после исследования Г. Шютца однозначно решен. Но в том же году, когда была защищена диссертация Г. Шютца, в 1994 г. была опубликована найденная в конце 80-х гг. XX в. надпись из Мопсуестии (Восточная Киликия) в статье антиковедов из Вены Ханса Тойбера, Петера Зиверта и стамбульского их коллеги Мустафы Хамди Заяра, посвященной анализу ее содержания и историческому фону ее составления [Sayar, Siewert, Taeuber, 1994, S. 113-130]. Затем надпись публиковалась Кентом Ригсби [Rigsby, 1996, p.465-471] и в Supplementum Epigraphicum Graecum [Supplementum, p. 436-438].

Надпись из Мопсуестии ${ }^{34}$ сохранилась на мраморном блоке, 60 см в высоту, 38 см в ширину и 16 см толщиной; был ли камень частью стены или храма, либо отдельной стелой, - не ясно. Отсутствуют начало и конец текста, начало строк 5-27 сохранилось, остальных - нет, окончания всех строк утрачены ${ }^{35}$.

После публикации киликийской надписи дискуссия пошла на новый круг, т. к. все опять запуталось, ибо в этой надписи должностное положение Л. Лукулла обозначено как

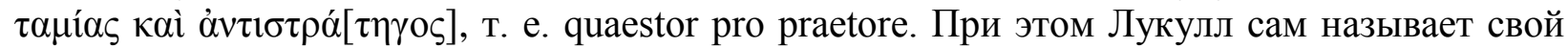
должностной статус, ошибиться он в этом случае не мог, неверное обозначение следует исключить. Это эпистолярный текст, но письмо тем не менее официальное. Поэтому текст

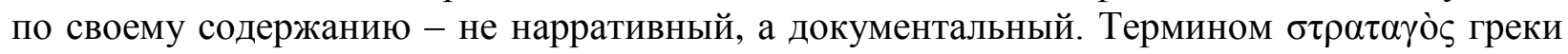
могли обозначать статус любого военачальника, но чаще всего - претора [см. об этом:

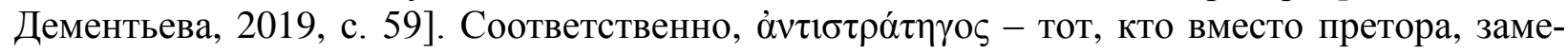
няющий его, в данном случае - квестор.

Надпись из Мопсуестии была продатирована 86 г. до н. э. сначала X. Тойбером [Sayar, Siewert, Taeuber, 1994, S. 119-120], а затем К. Ригсби [Rigsby, 1996, р. 466] и в Supplementum Epigraphicum Graecum [Supplementum, 1997, p. 436]. Получалось, следовательно, что и в 87 г., и 86 г. до н. э. - квестура Л. Лукулла, но два года подряд находиться в статусе данного магистрата он, очевидным образом, не мог. Ситуация становилась тем более неясной, поскольку Х. Тойбер не предложил датировать квестуру Лукулла 86 г. до н. э., а поддержал датировку квестуры Лукулла 87 г. [Sayar, Siewert, Taeuber, 1994, S. 118], солидаризировавшись в возврате к ней с Г. Шютцем.

В публикациях реконструкция текста инскрипции выглядит так (см. рис. 1):

${ }^{33}$ К этой диссертации непосредственно мы не обращались, приведенная отсылка содержится в работе Г. Шютца.

${ }^{34}$ Supplementum Epigraphicum Graecum XLIV. 1227.

35 Подробнее характеристику данного эпиграфического памятника см.: [Sayar, Siewert, Taeuber, S. 113-116]. 
[ [

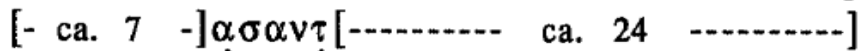

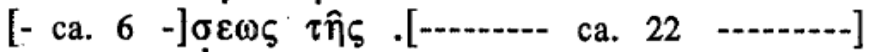

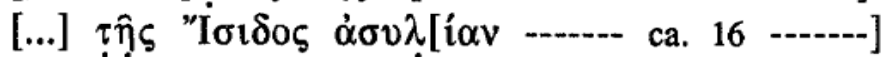

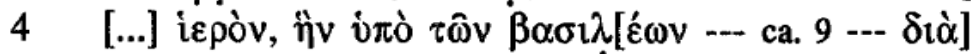

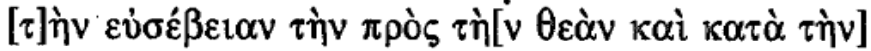

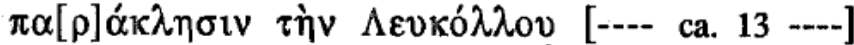

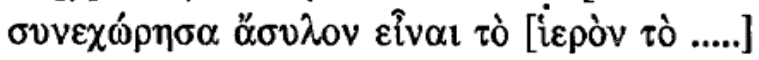

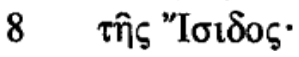

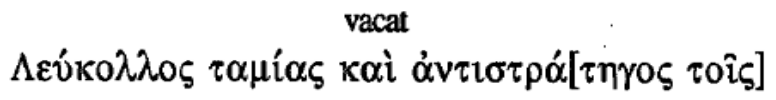

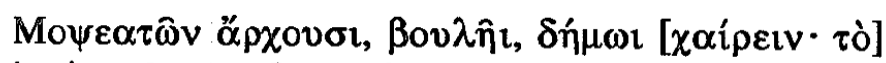

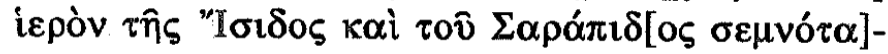

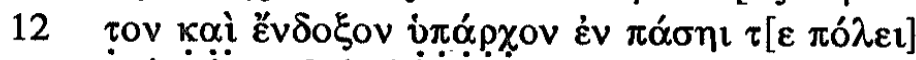

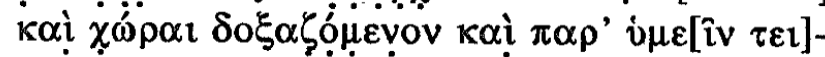

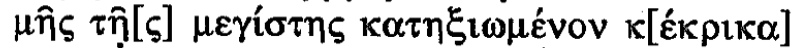

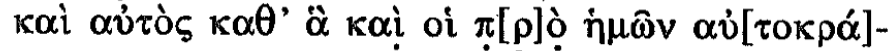

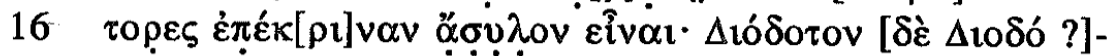

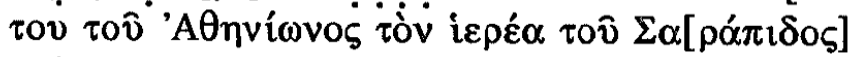

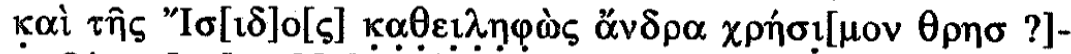
$\kappa \omega \delta \varepsilon ́ \sigma \tau \alpha[\tau \alpha]$ EI[.]

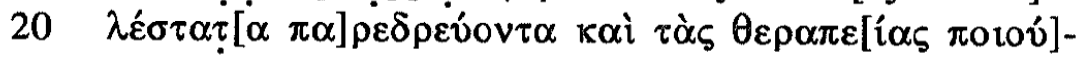

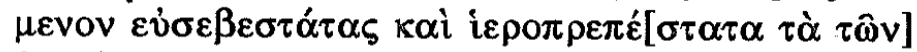

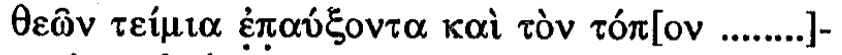

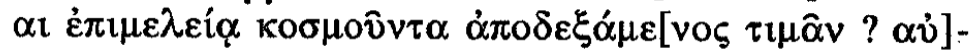

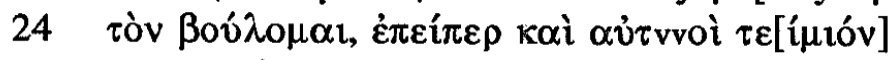

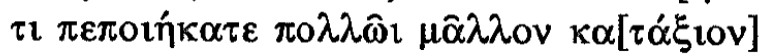

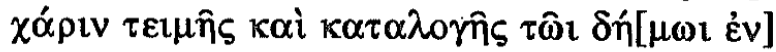

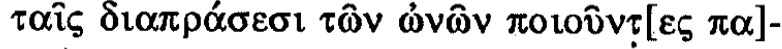

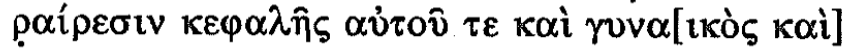

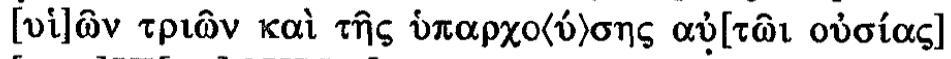
[.....]IT[...]OYPIO[-...... ca. 19 -.....-- ?] [

Рис. 1. Реконструкция надписи из Мопсуестии Fig. 1. Reconstruction of an inscription from Mopsuestia

X. Тойбер подчеркивал при этом, что аргументом в пользу такой даты служат не столько приведенные Г. Шютцем сопоставления титулатуры Лукулла по данным эпиграфики, сколько соображения следующего плана: такое достойное похвалы обстоятельство - то, что Лукулл, будучи квестором, остался в качестве единственного преданного Сулле полководца (на которое ссылался Э. Бэдиан в обосновании своей позиции) - не могло бы быть не упомянуто Плутархом в биографии Суллы: такой пример лояльности и доверия не мог быть обойден молчанием. Вместе с тем, как отмечено, Х. Тойбер не стал датировать письмо от имени Лукулла в Мопсуестию 87 г. до н. э. Он писал, что в таком случае следовало бы предположить, что посольство жителей Мопсуестии посетило Лукулла в Греции, так как в середине зимы 87/86 г. он предпринял морское путешествие. Но, с другой стороны, невероятно, - подчеркивал X. Тойбер, - что Лукулл составил это письмо в то время, когда его вышестоящий начальник, Сулла, находился в Греции, так как в этом случае обращались бы к нему как к носителю 
империя. Мыслимый период времени составления сжимается, на взгляд австрийского исследователя, до отрезка максимум от двух до трех месяцев, во время которых Лукулл был в Греции с авангардом Суллы, а тот сам с основным войском еще не прибыл туда. Из-за весьма небезопасных морских коммуникаций очень сомнительно, указывал Х. Тойбер, чтобы сообщение о прибытии Лукулла в Грецию так быстро удалось доставить в Киликию, и жители Мопсуетии тотчас направили к нему делегацию; флот Митридата и пираты, несомненно, воспрепятствовали бы такому контакту.

Поэтому, отказавшись считать 87 г. до н. э. временем составления письма, найденного в качестве эпиграфического памятника, Х. Тойбер предложил следующее объяснение. Хорошо известен факт, что Лукулл во время своего нахождения в Греции за счет храмовых сокровищ, награбленных Суллой из Олимпии, Дельф и Эпидавра, чеканил монету. Он выполнял, следовательно, - определяет Х. Тойбер, - функции «полевого (военного) квестора». Но такой квестор, - продолжает он рассуждения дальше, - который обычным образом находился в должности в течение похода, был, кроме того, представителем командующего в случае отсутствия последнего и мог выполнять особые задачи с наделением империем. В качестве примера таких действий Х. Тойбер привел миссию Пизона в Испании в 64 г. до н. э. (Sall. Cat. 19) и экспедицию Катона на Кипр в 58 г. до н. э. (Vell. II. 45). Поэтому, на взгляд Х. Тойбера, предоставление Лукуллу статуса quaestor pro praetore следует связать с его собиранием флота (в конце 87 г. Лукулл был послан Суллой в Египет и Ливию, чтобы попросить суда у дружественных правителей - Plut. Luc. II), а его письмо с большой вероятностью датировать 86 г. до н. э. - временем, когда он был в пути в Восточном Средиземноморье, собирая флот и вступая в контакт с слевкидскими городами. Итак, $\mathrm{X}$. Тойбер отнес квестуру Л. Лициния Лукулла к 87 г. до н. э., а надпись с фиксацией его

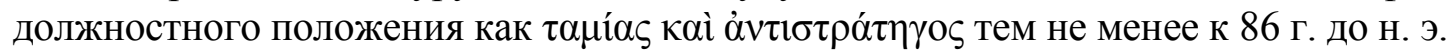

Против датировки квестуры Л. Лукулла 88 годом до н. э., которую стремился подкрепить Э. Бэдиан, выступил также Питер Тонеманн из университета Оксфорда, через 10 лет после диссертации Г. Шютца опубликовавший свою небольшую статью [Thonemann, 2004, p. 80-82], но не сославшийся на диссертацию предшественника (видимо, не использовавший ее), однако также исходивший из того, что на основе надписи из Гипаты квестура Л. Лукулла должна быть отнесена к 87 г. до н. э. Но если ко времени написания Г. Шютцем его исследования еще не была введена в научный обиход надпись из Мопсуестии в Восточной Киликии, датируемая в статье Х. Тойбером, как отмечено выше, 86 г. до н. э., где должностное положение Л. Лукулла обозначено как квестора pro praetore, то П. Тонеманн уже знал об этом факте, вступающем в противоречие с датировкой квестуры Л. Лукулла 87 годом. В итоге П. Тонеманн не согласился с Х. Тойбером в датировке надписи из Мопсуестии 86 г. до н. э., полагая, что она относится также к году именно квестуры Л. Лукулла, т. е. к 87 г. до н. э. Логика его рассуждений сводилась к тому, что в эпиграфических памятниках терминология, как правило, точна, она не может быть искажена небрежной записью - эпиграфическая практика сильно отличалась от практики написания литературных текстов. Если, подчеркивал П. Тонеманн, Цицерон (Сic. Pro Arch. 11) мог использовать обозначения quaestor/pro quaestore небрежно, то это не означает, что и в эпиграфическом источнике такая небрежность возможна, тем более в письме к киликийскому городу Лукулл сам называет свой титул. Для аргументации своей позиции П. Тонеманн привел ряд примеров: если эпиграфический материал, две надписи из Пергама (IGR IV. 400, 401), приводят для Луция Антония, брата триумвира, название должности

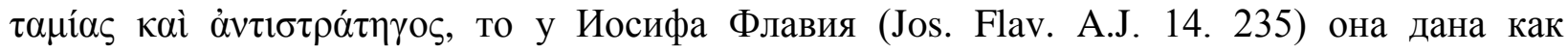

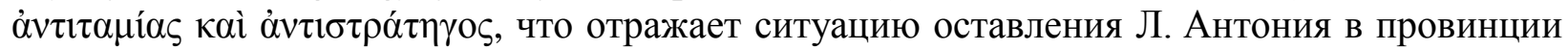
в 49 г. до н. э. после квестуры 50 г. до н. э. В целом П. Тонеманн призвал учитывать принцип строгой терминологической точности в эпиграфических текстах.

В 2006 г. Бернд Крайлер снова вернулся к вопросу о датировке квестуры Л. Лукулла [Kreiler, 2006, S. 73-82]. Он поддержал точку зрения о том, что квестура Л. Лукулла отно- 
сится к 87 г. до н. э. [Kreiler, 2006, S. 79], но не давал отсылок на работы своих предшественников (в частности, ни на диссертацию Г. Шютца, ни на статью П. Тонеманна) в аргументации этой датировки, указав только надпись из Гипаты основанием для таковой. Вместе с тем он сделал вывод: «Можно постулировать, что проквестор, который в сулланское время получал пропреторский империй в одной из провинций греческого Востока, в

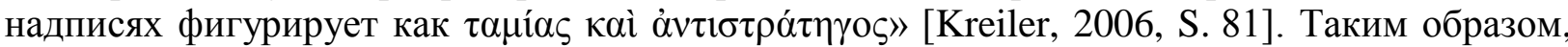
Б. Крайлер, проигнорировав наблюдения П. Тонеманна (судя по всему, к работе последнего, за два года перед тем опубликованной, он не обращался), утверждал прямо противоположное ему. Б. Крайлер оспаривал к тому же вывод Х. Тойбера о датировке надписи из Мопсуестии 86 г. до н. э., показывая несостоятельность примера, приведенного $\mathrm{X}$. Тойбером, о Кальпурнии Пизоне в качестве военного квестора в Испании, усматривая существенное различие: Пизон получил пропреторские полномочия по управлению провинцией от сената (Sall. Cat. 19. 2), в то время как плавание Лукулла не было военным предприятием, а представляло собой посольскую миссию. Б. Крайлер в итоге заключил, что Л. Лукулл был в Азии в статусе proquaestor pro praetore в 81/80 г. до н. э.

Мануэль Трёстер, подробно проанализировавший биографию Л. Лукулла в жизнеописаниях Плутарха, касаясь вопроса о датировке его квестуры [Tröster, 2008. p. 79-80], отметил, что, действительно, один релевантный текст с упоминанием таковой, происходящий из материковой Греции, который может с уверенностью быть отнесен к 87 г., и пять более поздних надписей из Эгеиды и Малой Азии, в которых статус Лукулла обозначен как проквесторской, находятся в соответствии с интерпретацией, данной Г. Шютцем и П. Тонеманном. М. Трёстер обратил внимание на то, что терминологическая передача должности Лукулла в надписи из Мопсуестии, предположительно датируемой 86 г. до н. э., не соответствует занятию квестуры Л. Лукуллом в 87 г., но заметил, что точность в названии римской магистратуры в текстах не всегда является сама собой разумеющейся [Tröster, 2008. p. 80]. Выводы Б. Крайлера М. Трёстер не обсуждал и не указывал его работу, вышедшую двумя годами ранее, в числе имеющих отношение к этому вопросу.

Авторы первой и единственной монографии по римской магистратуре квесторов, опубликованной в 2019 г., Франсиско Пина Поло и Алехандро Диас Фернадес придерживаются датировки квестуры Л. Лициния Лукулла 87 годом, относя его проквестуру к 86-80 гг. до н. э. [Pina Polo, Díaz Fernández, 2019, p. 152-153; 275, 340]. Специальный раздел в данной книге посвящен просопографии, в котором, разумеется, есть и информация о Лукулле, в частности приводятся наименования его должности из ряда надписей, но среди этого перечисления нет обозначения его статуса, отраженного в надписи из Мопсуестии [Pina Polo, Díaz Fernández, 2019, p. 275], как нет в библиографическом списке названных нами выше работ М.Х. Заяра, П. Зиверта и Х. Тойбера, а также Б. Крайлера и М. Трёстера. Тем самым, к сожалению, новые вопросы, которые ставит перед исследователями надпись из Мопсуестии, не находят в монографии Ф. Пина Поло и А. Диаса Фернадеса отклика, как, собственно, и не обсуждается в ней статус quaestor pro praetore как таковой.

\section{Выводы}

В целом, как видим, в историографии вопроса сложилась такая картина. Квестура Луция Лициния Лукулла датируется 87 г. до н. э. (в дискуссиях о датировке долгое время конкурировавшая дата -88 г. до н. э. - уже фактически безнадежно «проиграла»). Однако надпись из Мопсуестии, продатированная всеми издателями 86 г. до н. э., заставила исследователей искать объяснение тому факту, что в ней Лукулл назван квестором с пропреторскими полномо-

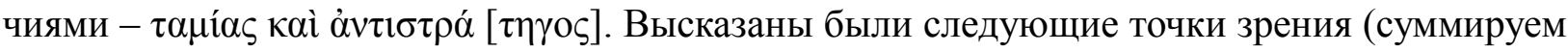
их в хронологической последовательности публикации в научной литературе):

1. «Военные квесторы» могли оставаться таковыми за пределами административного года, если поход не закончился, при этом они не назывались проквесторами, поэтому в 
случае получения полномочий pro praetore имели обозначение quaestor pro praetore / $\tau \alpha \mu$ í

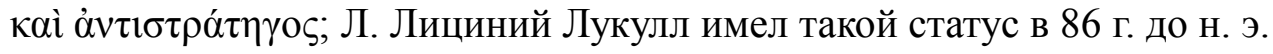

2. Proquaestor pro praetore мог ошибочно называться в надписях (как и в нарративных текстах) квестором; признание возможности такой ошибки позволяет датировать надпись из Мопсуестии 86 г. до н. э.

3. Ошибку написания «квестор» вместо «проквестора» в эпиграфических памятниках следует исключить и считать ошибочной датировку киликийской надписи 86 г. до н. э., признав тем самым, что именно в 87 г. до н. э. Л. Лукулл, будучи квестором, исполнял пропреторские обязанности.

4. Никакой ошибки в обозначении должности нет; это не ошибка, а практика сулланского времени - обозначение проквесторов с пропреторскими полномочиями в греческих

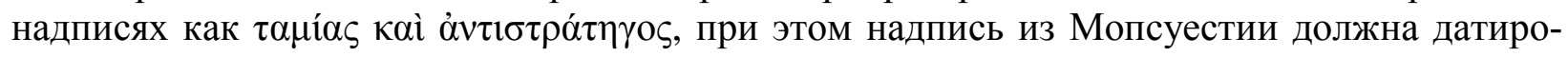
ваться 81/80 г. до н. э., что не мешает относить квестуру Л. Лукулла к 87 г. до н. э.

Такой разброс мнений, явная спорность последнего по времени из них, а также то, что позиции исследователей формулировались далеко не всегда в диалоге, хотя бы и заочном, а высказывались параллельно, невзирая на уже опубликованные контрдоводы, означает необходимость нового обращения к данному вопросу. При этом мы полагаем, что надо проанализировать имеющуюся информацию обо всех известных случаях функционирования квесторов и проквесторов pro praetore, чтобы конкретную ситуацию Л. Лициния Лукулла понять в контексте римской практики предоставления низшим магистратам и промагистратам преторских полномочий; только после этого можно делать выводы и о датировке квестуры, а соответственно, начала проквестуры этого римского политического и военного деятеля.

\section{Список литературы}

1. Дементьева В.В. 2013а. Греческие надписи о квестуре и проквестуре Л. Лициния Лукулла. Вестник Ярославского государственного университета им. П.Г. Демидова. Серия Гуманитарные науки. 4: 14-19.

2. Дементьева В.В. 2013б. Делосская латинская надпись о проквестуре Лукулла: Луций или Марк? Проблемы истории филологии и культуры. 4: 54-62.

3. Дементьева В.В. 2015. Надпись из Дельф (Supplementum Epigraphicum Graecum I. 153): квестор - Луций Лициний Лукулл? Иресиона. Античный мир и его наследие. Вып. IV. Сборник научных трудов к 50-летию профессора Н.Н. Болгова. Е.В. Литовченко, С.Н. Прокопенко, Е.А. Семичева (ред. кол.). Белгород, «Эпицентр», 119-125.

4. Дементьева В.В. 2019. Родосская надпись (Sylloge Inscriptionum Graecarum³ ${ }^{3}$ № 745): что связывало грека Поликла с римскими должностными лицами? Lumen intellectus. Памяти Ии Леонидовны Маяк. Сборник статей Научно-образовательного центра антиковедения ЯрГУ. Отв. ред. В.В. Дементьева. Ярославль, Филигрань, 53-67.

5. Ameling W. 1989. Licinius Lucullus in Chios. Zeitschrift für Papyrologie und Epigraphik. Bd. 77: 98-100.

6. Badian E. 1964. Studies in Greek and Roman History. Oxford, VIII + 290.

7. Broughton T.R.S. 1986a. The Magistrates of the Roman Republic. Vol. III. Atlanta, Georgia, IX +294 .

8. Broughton T.R.S. 1986b. The Magistrates of the Roman Republic. Vol. II. Atlanta, Georgia, IX+647.

9. Clerc M.A. Inscriptions de Thyatire et des environs. Bulletin de correspondance hellénique. 1886. Vol. 10: 398-423.

10. Choix d'inscriptions de Délos. 1923. Fasc. II. Avec traduction et commentaire par F. Dürrbach. Textes historiques. Paris, 294.

11. Corpus Inscriptionum Latinarum. 1918. Vol. I². Pars II. Fasc. I. Inscriptiones Latinae antiquissimae. Cura E. Lommatzsch. Berolini, 852.

12. Corpus Inscriptionum Latinarum. 1873. Vol. III. Pars I. Inscriptiones Asiae, provinciarum Europae Graecarum, Illyrici Latinae. Ed. Th. Mommsen. Berolini, 586. 
13. Gelzer M. 1926. L. Licinius Lucullus. Real-Encyclopädie der classischen Altertumswissenschaft / A. Pauly, G. Wissowa (Hrsg.). Vol. XIII: 376-414.

14. Inscriptiones Latinae Selectae. 1892. Vol. 1. Ed. H. Dessau. Berlin, 580.

15. Keaveney A. 1992. Lucullus. A Life. London and New York, 296.

16. Kreiler B.M. Der Prokonsul Lentulus, der Imperator Murena und der Proquästor Lucullus. Tyche. Beiträge zur alten Geschichte, Papyrologie und Epigraphik. 2006. Bd. 21: 73-82.

17. Ooteghem, van J. 1959. Lucius Licinius Lucullus. Brussels, 236.

18. Pina Polo F., Díaz Fernández A. 2019. The Quaestorship in the Roman Republic. Berlin/Boston: Klio Beihefte, De Gruyter, 376.

19. Pomtow H. 1921. Delfische Neurfunde. Klio. Bd. 17: 163-164.

20. Ramsay W.M. 1883. Unedited Inscriptions of Asia Minor. Bulletin de correspondance hellénique. Vol. 7: 297-328.

21. Rigsby K.J. 1996. Asylia. Territoirial Inviolability in The Hellinic World. Berkeley, 835.

22. Sayar M.H., Siewert P., Taeuber H. 1994. Asylie-Erklärungen des Sulla und des Lucullus für das Isis- und Sarapisheiligtum von Mopsuhestia (Ostkilikien). Tyche. Beiträge zur Alten Geschichte, Papyrologie und Epigraphik. Bd. 9: 113-130.

23. Schütz G. 1994. L. Licinius Lucullus. Studien zu den frühen Jahren eines Nobilis (117-75 v. Chr.). Regensburg, $149+$ XVI.

24. Sobeck F. 1909. Die Quästoren der Römischen Republik. Trebnitz, 95.

25. Supplementum Epigraphicum Graecum. 1994. Vol. XLIV. Amsterdam. 1997, XXXVIII +705 .

26. Thonemann P.J. 2004. The Date of Lucullus' Quaestorship. Zeitschrift für Papyrologie und Epigraphik. Bd. 149: 80-82.

27. Tröster M. 2008. Themes, Character and Politics in Plutarch's Life of Lucullus. The Construction of a Roman Aristocrat. Stuttgart, 206.

28. Wosnik B. 1963. Untersuchungen zur Geschichte Sullas. Würzburg, 125.

\section{Referenses}

1. Dementyeva V.V. 2013a. Grecheskie nadpisi o kvesture i prokvesture L. Licinija Lukulla [The Greek inscriptions about Quaestorship and Proquaestorship of Lucius Licinius Lucullus]. Vestnik Yaroslavskogo gosudarstvennogo universiteta im. P.G. Demidova. Serija Gumanitarnye nauki [Bulletin of the Yaroslavl State University. P.G. Demidov. Series the Humanities]. 4: 14-19.

2. Dementyeva V.V. 2013b. Delosskaja latinskaja nadpis' o prokvesture Lukulla: Lucij ili Mark? [Delossian Latin Inscription Concerning Lucullus Proquesture: Lucius or Marcus?]. Problemy istorii filologii i kul'tury [Journal of Historical, Philological and Cultural Studies]. 4: 54-62.

3. Dementyeva V.V. 2015. Nadpis' iz Del'f (Supplementum Epigraphicum Graecum I. 153): kvestor - Lucij Licinij Lukull? [The Inscription from Delphi (Supplementum Epigraphicum Graecum I. 153): Quaestor - Lucius Licinius Lucullus?] IRESIONA. Antichnyj mir i ego nasledie. Vyp. IV. Sbornik nauchnyh trudov k 50-letiju professora N.N. Bolgova [Iresiona. The ancient world and its heritage. Issue IV. Collection of scientific papers dedicated to the 50th anniversary of Professor N.N. Bolgov]. Eds. E.V. Litovchenko, S.N. Prokopenko, E.A. Semicheva (red. kol.). Belgorod, Epicentr, 119-125.

4. Dementyeva V.V. Rodosskaja nadpis' (Sylloge Inscriptionum Graecarum³, № 745): chto svjazyvalo greka Polikla s rimskimi dolzhnostnymi licami? [The Rhodes Inscription (Sylloge Inscriptionum Graecarum3, № 745): what connected the Greek Polykles with Roman Officials?] Lumen intellectus. Pamjati Ii Leonidovny Majak. Sbornik statej Nauchno-obrazovatel'nogo centra antikovedenija JarGU [Lumen intellectus. In memory of Iya Leonidovna Mayak. Collection of articles of the Scientific and Educational Center for Antiquity of YarSU]. Ed. V.V. Dementyeva. Jaroslavl': Filigran', 53-67.

5. Ameling W. 1989. Licinius Lucullus in Chios. Zeitschrift für Papyrologie und Epigraphik. Bd. 77: 98-100.

6. Badian E. 1964. Studies in Greek and Roman History. Oxford, VIII + 290.

7. Broughton T.R.S. 1986a. The Magistrates of the Roman Republic. Vol. III. Atlanta, Georgia, $\mathrm{IX}+294$.

8. Broughton T.R.S. 1986b. The Magistrates of the Roman Republic. Vol. II. Atlanta, Georgia, IX+647. 
9. Clerc M.A. Inscriptions de Thyatire et des environs. Bulletin de correspondance hellénique. 1886. Vol. 10: 398-423.

10. Choix d'inscriptions de Délos. 1923. Fasc. II. Avec traduction et commentaire par F. Dürrbach. Textes historiques. Paris, 294.

11. Corpus Inscriptionum Latinarum. 1918. Vol. $\mathrm{I}^{2}$. Pars II. Fasc. I. Inscriptiones Latinae antiquissimae. Cura E. Lommatzsch. Berolini, 852.

12. Corpus Inscriptionum Latinarum. 1873. Vol. III. Pars I. Inscriptiones Asiae, provinciarum Europae Graecarum, Illyrici Latinae. Ed. Th. Mommsen. Berolini, 586.

13. Gelzer M. 1926. L. Licinius Lucullus. Real-Encyclopädie der classischen Altertumswissenschaft / A. Pauly, G. Wissowa (Hrsg.). Vol. XIII: 376-414.

14. Inscriptiones Latinae Selectae. 1892. Vol. 1. Ed. H. Dessau. Berlin, 580.

15. Keaveney A. 1992. Lucullus. A Life. London and New York, 296.

16. Kreiler B.M. Der Prokonsul Lentulus, der Imperator Murena und der Proquästor Lucullus. Tyche. Beiträge zur alten Geschichte, Papyrologie und Epigraphik. 2006. Bd. 21: 73-82.

17. Ooteghem, van J. 1959. Lucius Licinius Lucullus. Brussels, 236.

18. Pina Polo F., Díaz Fernández A. 2019. The Quaestorship in the Roman Republic. Berlin/Boston: Klio Beihefte, De Gruyter, 376.

19. Pomtow H. 1921. Delfische Neurfunde. Klio. Bd. 17: 163-164.

20. Ramsay W.M. 1883. Unedited Inscriptions of Asia Minor. Bulletin de correspondance hellénique. Vol. 7: 297-328.

21. Rigsby K.J. 1996. Asylia. Territoirial Inviolability in The Hellinic World. Berkeley, 835.

22. Sayar M.H., Siewert P., Taeuber H. 1994. Asylie-Erklärungen des Sulla und des Lucullus für das Isis- und Sarapisheiligtum von Mopsuhestia (Ostkilikien). Tyche. Beiträge zur Alten Geschichte, Papyrologie und Epigraphik. Bd. 9: 113-130.

23. Schütz G. 1994. L. Licinius Lucullus. Studien zu den frühen Jahren eines Nobilis (117-75 v. Chr.). Regensburg, $149+$ XVI.

24. Sobeck F. 1909. Die Quästoren der Römischen Republik. Trebnitz, 95.

25. Supplementum Epigraphicum Graecum. 1994. Vol. XLIV. Amsterdam. 1997, XXXVIII +705 .

26. Thonemann P.J. 2004. The Date of Lucullus' Quaestorship. Zeitschrift für Papyrologie und Epigraphik. Bd. 149: 80-82.

27. Tröster M. 2008. Themes, Character and Politics in Plutarch's Life of Lucullus. The Construction of a Roman Aristocrat. Stuttgart, 206.

28. Wosnik B. 1963. Untersuchungen zur Geschichte Sullas. Würzburg, 125.

Конфликт интересов: о потенциальном конфликте интересов не сообщалось.

Conflict of interest: no potential conflict of interest related to this article was reported.

\section{ИНФОРМАЦИЯ ОБ АВТОРЕ}

Дементьева Вера Викторовна, доктор исторических наук, профессор кафедры всеобщей истории Ярославского государственного университета им. П.Г. Демидова, г. Ярославль, Россия

\section{INFORMATION ABOUT THE AUTHOR}

Vera V. Dementyeva, doctor of Historical Sciences, Professor of the Department of General History of the Yaroslavl State University P.G. Demidova, Yaroslavl, Russia 